\title{
Preparation of New Uric Acid Sensors Based on Iodide Selective Electrode
}

\author{
Şükrü Kalaycı \\ Department of Chemistry, Gazi University, Ankara, Turkey \\ Email: skalayci@gazi.edu.tr
}

How to cite this paper: Kalayc1, S. (2020) Preparation of New Uric Acid Sensors Based on Iodide Selective Electrode. American Journal of Analytical Chemistry, 11, 205-212.

https://doi.org/10.4236/ajac.2020.115016

Received: April 20, 2020

Accepted: May 18, 2020

Published: May 21, 2020

Copyright $\odot 2020$ by author(s) and Scientific Research Publishing Inc. This work is licensed under the Creative Commons Attribution International License (CC BY 4.0).

http://creativecommons.org/licenses/by/4.0/

(c) (i) Open Access

\begin{abstract}
An electrode for uric acid has been prepared by using an iodide selective electrode with the uricase enzyme. The iodide selective electrode used was prepared from $10 \%$ TDMAI and PVC according to our previous study. The enzyme was immobilized on the iodide electrode by holding it at $\mathrm{pH} 7$ phosphate buffer for $20 \mathrm{~min}$ at room temperature. The $\mathrm{H}_{2} \mathrm{O}_{2}$ formed from the reaction of uric acid was determined from the decrease of iodide concentration that was present in the reaction cell. The potential change was linear in the $2 \times 10^{-5}$ to $2 \times 10^{-4} \mathrm{M}$ uric acid concentration (3 - $34 \mathrm{mg}$ uric acid $/ 100 \mathrm{ml}$ blood) range. Uric acid contents of some blood samples were determined with the new electrode and consistency was obtained with a colorimetric method. The effects of $\mathrm{pH}$, iodide concentration, the amount of enzyme immobilized and the operating temperature were studied. No interference of ascorbic acid, glucose and urea was observed.
\end{abstract}

\section{Keywords}

Uric Acid Electrode, Uricase, Enzyme, Iodide Selective Electrode, Uric Acid in Blood

\section{Introduction}

Enzyme electrodes are being used for the measurement of different organic substrates. In most of them potentiometric sensors, e.g. oxygen [1] carbon dioxide [2], or ammonium ion electrodes [3] have been used, but some of them use different voltammetric measuring techniques.

Determination of uric acid in body fluids is a clinically valuable diagnostic indicator. The presence of elevated uric acid levels is a sign of gout, hyperuricemia, or Lesch-Nyhan syndrome [4]. The development of an electrochemical uric acid biosensor with an immobilized enzyme on an electrode surface has been the aim 
of several recent studies [5] [6] [7]. In some of these procedures the enzyme uricase is used. This enzyme catalyzes the oxidation of uric acid to allontoin in the presence of carbon dioxide and hydrogen peroxide is formed. Hydrogen peroxide formed during this reaction can be determined with amperometric [5] [6] [8] or potentiometric sensors [9] [10] [11] [12].

A novel optical detection system consisting of combination of uricase/HRP-CdS quantum dots (QDs) for the determination of uric acid in urine sample is described. The QDs were used as an indicator to reveal fluorescence property of the system resulting from enzymatic reaction of uricase and HRP (horseradish peroxidase), which is involved in oxidizing uric acid to allaintoin and hydrogen peroxide. The linearity of the system toward uric acid was in the concentration range of $125-1000 \mu \mathrm{M}$ with detection limit of $125 \mu \mathrm{M}$ [13].

An electrochemical biosensor based on gold and palladium nano particlesmodified nanoporous stainless steel (Au-Pd/NPSS) electrode has been introduced for the simultaneous determination of levodopa (LD) and uric acid (UA). Differential pulse voltammetry (DPV) was used for the simultaneous determination of LD and UA [14].

In this study, uricase was trapped in plasticized PVC and iodide ion selective electrode was used to monitor iodide. This electrode has an average slope of 63 $\mathrm{mV} /$ ten uric acid. When this electrode is used 4 times a day, it has a life of 70 days. The electrode is not sensitive to glucose and ascorbic acid. This study describes the preparation and application of a new potentiometric uric acid sensor.

\section{Experimental}

\subsection{Apparatus and Reagents}

Potential measurements were made with JENWAY 3030 Ion Analyser. "A double junction $\mathrm{Ag} / \mathrm{AgCl}$ electrode 9240368 " was used as the outer reference electrode. The enzyme was immobilized on our previously prepared iodide electrode. For the $\mathrm{pH}$ measurements, the ion analyzer with 924005 combined $\mathrm{pH}$ electrode is used. All measurements were made with a $30 \mathrm{ml}$ glass cell prepared for this purpose. A magnetic stirrer was used throughout the experiments. All reagents used were analytical reagent grade (Merck). Triply distilled water was used for the preparation of solutions.

\subsection{Preparation of Electrode}

The iodide electrode in which the enzyme was fixed was prepared according to the procedure developed by us [15]. For this purpose, approximately $180 \mathrm{mg}$ of PVC and $60 \mathrm{mg}$ of ion exchanger (tridodecylmethylammonium iodide) are dissolved in $5 \mathrm{ml}$ of tetrahydrofuran (THF). Then $0.2 \mathrm{ml}$ of plasticizer (dibutyl phthalate) is added and mixed. After evaporation of the solvent the film membrane is cemented to a PVC tube with inner diameter of $10 \mathrm{~mm}$, the tube is filled with 0.1 $\mathrm{M} \mathrm{KI}$ and $0.1 \mathrm{M} \mathrm{NaCl}$ solution. A home-made $\mathrm{Ag} / \mathrm{AgCl}$ electrode is immersed as the inner reference. 
For the immobilization procedure, first $10 \mathrm{mg}$ of enzyme is dissolved in $5 \mathrm{ml}$ phosphate buffer $(\mathrm{pH}=7)$. The iodide electrode prepared as the above given procedure is kept in it for $2 \mathrm{~h}$ at room temperature. This electrode was stored in $\mathrm{pH} 7$ buffer at $+2^{\circ} \mathrm{C}$ when not in use. The measurements are made in $19 \mathrm{ml} \mathrm{pH} 7$ phosphate buffer, $1 \mathrm{ml} 1 \times 10^{-3} \mathrm{M} \mathrm{Mo}(\mathrm{VI})$ and in the presence of $0.01 \mathrm{M}$ iodide solution.

\section{Result and Discussion}

Uric acid is oxidized by air oxygen in the presence of uricase enzyme and hydrogen peroxide is formed, which reacts with iodide ion quantitatively. Thus, this reaction can be used for the determination of uric acid when known concentration of iodide is present. The decrease of iodide concentration will be proportional to uric acid concentration according to the following reactions.

$$
\begin{gathered}
\text { Uric acid }+\mathrm{O}_{2} \stackrel{\text { uricase }}{\longrightarrow} \text { allantoin }+\mathrm{CO}_{2}+\mathrm{H}_{2} \mathrm{O}_{2} \\
\mathrm{H}_{2} \mathrm{O}_{2}+2 \mathrm{I}^{-} \stackrel{\mathrm{Mo}(\mathrm{VI})}{\longrightarrow} \mathrm{I}_{2}+\mathrm{H}_{2} \mathrm{O}
\end{gathered}
$$

Molybdenum (VI) or peroxidase enzyme can be employed as the catalyst the last has the advantage of higher efficiency [9] [10] [11]. As can be seen two moles of iodide are used for one mole of uric acid. Thus the change of concentration of iodide after reaction with uric acid can be used for the determination of uric acid. In this work we used iodide electrode for the determination of iodide concentration before and after the reaction with uric acid.

\subsection{Effect of Iodide Concentration}

Since one mole of uric acid uses two moles of iodide its concentration has to be higher than uric acid concentration. The optimum concentration of iodide has to be determined for a uric acid concentration that is in the range of glucose present in blood. For this purpose, solutions with $19 \mathrm{ml} \mathrm{pH} 7$ phosphate buffer and $1 \mathrm{ml} 1 \times 10^{-3} \mathrm{M}(\mathrm{Mo}(\mathrm{VI}))$ have been prepared containing various iodide concentrations of $1 \times 10^{-4}, 1 \times 10^{-3}$ and $1 \times 10^{-2} \mathrm{M}$. Their potentials were measured and then after each uric acid addition once more the potentials were measured. The uric acid concentrations in the cell were in the range of blood serum, changing from $2 \times 10^{-5} \mathrm{M}(3 \mathrm{mg} / 100 \mathrm{ml})$ to $2 \times 10^{-4} \mathrm{M}$ (34 mg/100ml blood). As can be seen from Figure 1 the slope was the highest for $10^{-2} \mathrm{M}$ iodide concentration.

\subsection{Effect of pH and Buffer Concentration}

Adjustment of $\mathrm{pH}$ is important both for the immobilization of enzyme and for the reaction between hydrogen peroxide and iodide. At different $\mathrm{pH}$ values changing from 9 to 5.5 the response of electrode has been measured against uric acid concentration when $0.01 \mathrm{M}$ iodide was present. Whereas there was nearly no response at $\mathrm{pH}$ values of 5.5, 6, 6.5, 8 and 9 the slope was the largest at $\mathrm{pH} 7$. At this $\mathrm{pH}$ the ion exchanger (mentioned in Section 3.3) is positive and enzyme 


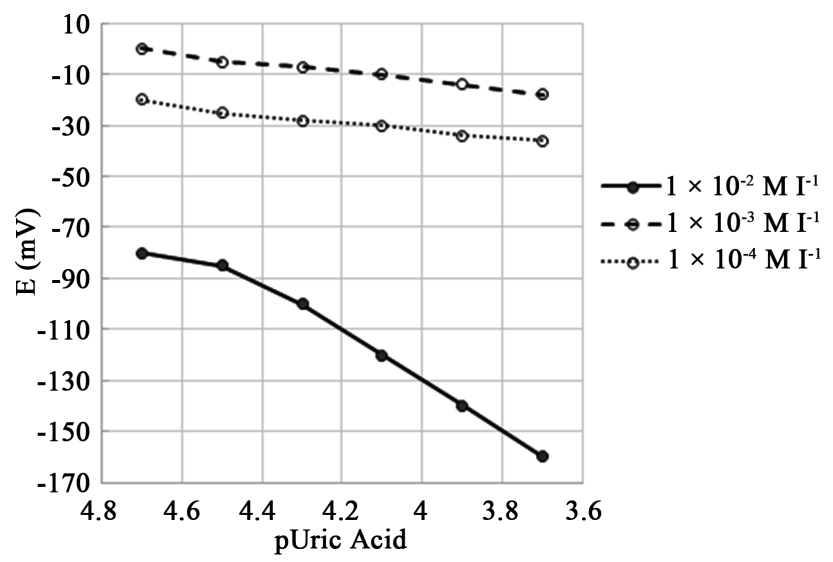

Figure 1. The effect of iodide concentration on the slope of the electrode.

is negative, thus it is the most convenient $\mathrm{pH}$ for immobilization and for the reaction.

Phosphate buffer has been chosen because of its $\mathrm{pH}$ working area. Its response for uric acid has been investigated at buffer concentrations changing from 1.0 to $10^{-3} \mathrm{M}$. The change of potential against uric acid concentration is given in Figure 2. As can be seen $0.1 \mathrm{M}$ buffer concentration had the largest slope.

\subsection{Immobilization of Enzyme}

The ion exchanger (TDMAI) on the iodide electrode becomes a positive charge at $\mathrm{pH}=7$, at this $\mathrm{pH}$ the enzyme becomes minus charge and thus the enzyme will be immobilized on the electrode surface. The quantity of enzyme will be important since only one part of it can be immobilized on the electrode surface. For this purpose, iodide electrode was dipped into $\mathrm{pH} 7$ phosphate buffer solutions each containing 5, 10 and $20 \mathrm{mg} / \mathrm{ml}$ enzyme for $2 \mathrm{~h}$. It was washed with distilled water and its response has been measured for uric acid concentrations in the presence of $0.01 \mathrm{M}$ iodide. As can be observed from Figure 3, the slope was the largest for $10 \mathrm{mg} / \mathrm{ml}$ enzyme.

\subsection{Effect of Temperature}

Optimum temperature is very important since the enzyme activity will increase with temperature, but on the other hand at high temperatures there may be thermal deactivation of the enzyme and also decrease of $\mathrm{O}_{2}$ concentration. In a solution containing $0.01 \mathrm{M}$ iodide, the potential of a solution of $1 \times 10^{-4} \mathrm{M}$ uric acid has been followed between temperatures of $30^{\circ} \mathrm{C}-60^{\circ} \mathrm{C}$ within $5^{\circ} \mathrm{C}$ intervals. The maximum activity of the enzyme was obtained at $50^{\circ} \mathrm{C}$ (Figure 4).

\subsection{Response and Lifetime}

This electrode did not lose its activity for 45 days when used 4 times a day. The response time was measured at different uric acid concentrations. As can be seen from Figure 5 the response was almost immediate. The lifetime of the electrode is also very good compared with other electrodes [6] [8] [10] [11] [15]. 


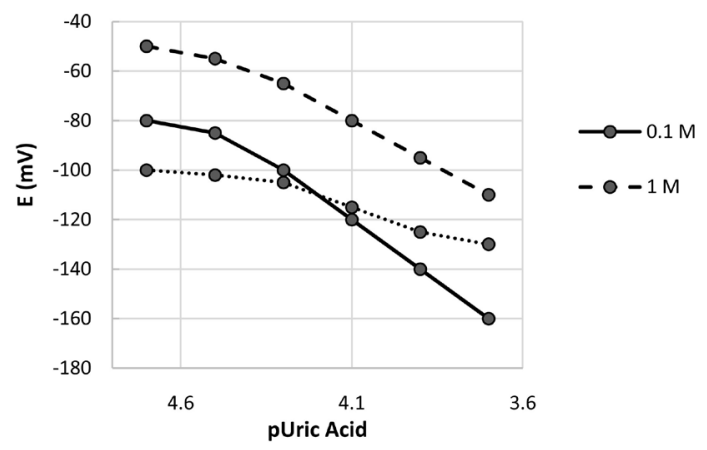

Figure 2. The change of potential with buffer concentration $\left(1 \times 10^{-2} \mathrm{M} \mathrm{I}^{-}\right)$.

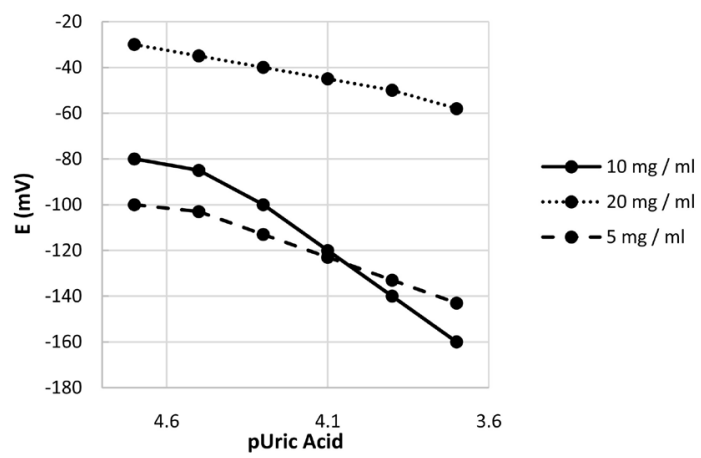

Figure 3. The effect of immobilized enzyme quantity on the slope of the electrode $\left(1 \times 10^{-2} \mathrm{M} \mathrm{I}^{-}\right)$.

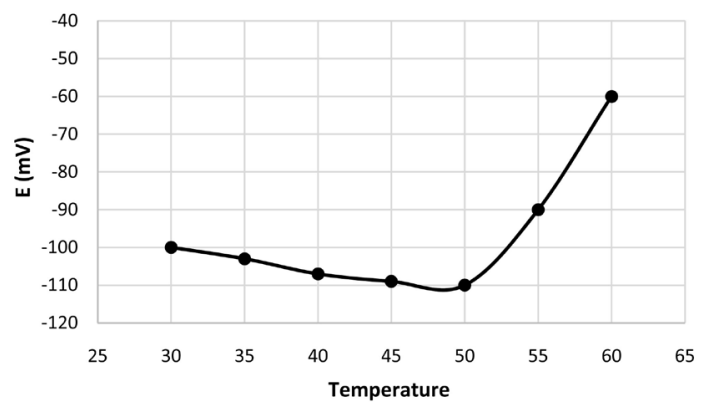

Figure 4. The effect of temperature on the activity of enzyme $\left(2 \times 10^{-4} \mathrm{M}\right.$ uric acid, $1 \times 10^{-2} \mathrm{M} \mathrm{I}^{-}$).

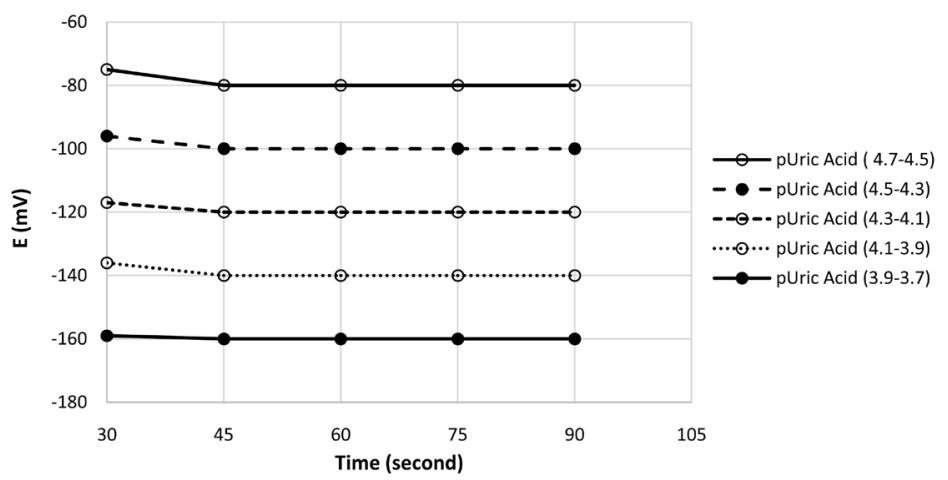

Figure 5. The dependence of response time of the electrode on the change of concentration. 


\subsection{Interference Studies}

The product of enzymatic reaction is hydrogen peroxide, thus reducing agents such as glucose and ascorbic acid, two compounds commonly found in biological fluids, may interfere [8] [9]. The strong interference of glucose and ascorbic acidin a former study [9] was eliminated after pretreatment with hydrogen peroxide. With our new electrode in the presence of $0.01 \mathrm{M}$ iodide and $2 \times 10^{-5} \mathrm{M}$ uric acid there was no interference from the above mentioned substances in the concentration ranges that are commonly encountered in biological fluids ( 0 - 2.5 $\mathrm{mM})$. The selectivity constants determined by using the mixed solution method [16] are given in Table 1.

\subsection{Measurement of Uric Acid in Blood Serum}

It was found that, with this new electrode the uric acid could be determined with high accuracy and precision (Table 2). For a solution containing $5 \mathrm{mg} / 100 \mathrm{ml}$ the result obtained for 4 measurements was $4 \pm 0.1 \mathrm{mg} / 100 \mathrm{ml}$.

The blood samples that were analyzed for their uric acid quantity were obtained from the University Health Center. They were first centrifuged with a speed of $9000 \mathrm{round} / \mathrm{min}$ and these were used for uric acid determination. First the potential of a solution containing $19 \mathrm{ml}$ buffer $(\mathrm{pH}=7), 1 \mathrm{ml} 1 \times 10^{-3} \mathrm{M} \mathrm{Mo}$ (VI) and $0.01 \mathrm{M}$ iodide was measured. A $0.1 \mathrm{ml}$ of serum sample was added and the potential was once more measured. Then two standard additions of $0.1 \mathrm{M}$ uric acid (each $0.1 \mathrm{ml}$ ) were made and potentials were measured. From the change of potentials, the amount of uric acid in blood was determined. Blood samples shall not wait long time; otherwise uric acid will be lost because of destruction. If it has to wait additions of fluoride or ascorbic acid is needed. Glucose quantities for three different blood samples are given in Table 3 with the results of University Health Center (colorimetric) for comparison.

Table 1. Selectivity coefficient $\left(\mathrm{K}_{\mathrm{A}, \mathrm{B}}^{\mathrm{pot}}\right.$ ) for the uric acid electrode in mixed solutions (in the presence of $1 \times 10^{-5} \mathrm{M}$ uric acid $)^{\mathrm{a}}$.

\begin{tabular}{ccc}
\hline & \multicolumn{2}{c}{ B } \\
\cline { 2 - 3 } & Glucose & Ascorbic acid \\
\hline $\mathrm{K}_{\mathrm{A}, \mathrm{B}}^{\mathrm{pot}}$ & $2.3 \times 10^{-4}$ & $3.4 \times 10^{-4}$ \\
\end{tabular}

${ }^{\mathrm{a}} \mathrm{A}$ : Uric acid; B: Interfering ion.

Table 2. Determinations of uric acid in a known samples ${ }^{\mathrm{a}}$.

\begin{tabular}{cccc}
\hline Uric acid $(\mathrm{mg} / 100 \mathrm{ml})$ & \multicolumn{3}{c}{$\begin{array}{c}\text { Uric acid determined with the new electrode } \\
(\mathrm{mg} / 100 \mathrm{ml})\end{array}$} \\
\hline$X_{i}$ & $\bar{X}$ & $\mathrm{~S}$ & $\mathrm{CI}^{*}$ \\
4 & 4.1 & 0.012 & $4.1 \pm 0.2$
\end{tabular}

CI: $95 \%, N=4$ 
Table 3. Uric acid levels in the four different blood samples.

\begin{tabular}{cc}
\hline $\begin{array}{c}\text { Quantity given from } \\
\text { health center }(\mathrm{mg} / 100 \mathrm{ml})\end{array}$ & $\begin{array}{c}\text { Uric acid levels, with the } \\
\text { new electrode }(\mathrm{mg} / 100 \mathrm{ml})\end{array}$ \\
4.5 & $4.4 \pm 0.2$ \\
6.2 & $6.3 \pm 0.3$ \\
3.9 & $3.8 \pm 0.1$ \\
10.6 & $10.7 \pm 0.5$ \\
\hline
\end{tabular}

$95 \% \mathrm{CI}, \mathrm{N}=4$

\section{Conclusion}

A new enzyme based electrode is prepared by using an iodide selective electrode. Here one electrode works as enzyme holder and at the same time it monitors the iodide concentration. Since the iodide electrode is constructed with an ion exchanger and not with AgI, it does not show any interference of most common ions such as chloride and sulfate. The prepared sensor displayed very good performance in regard to reproducibility, sensitivity and long lifetime. It shows linear response in the $3-34 \mathrm{mg} / 100 \mathrm{ml}$ concentration range with a slope of about $63 \mathrm{mV}$ per decade change of uric acid.

\section{Acknowledgements}

The author thanks to the Gazi University research fund for the financial support of this research.

\section{Conflicts of Interest}

The author declares no conflict of interest.

\section{References}

[1] Updike, S. and Hicks, G.P. (1967) Reagentless Substrate Analysis with Immobilized Enzymes. Science, 158, 270-272. https://doi.org/10.1126/science.158.3798.270

[2] Kalcher, K., Svancara, I., Buzuk, M., Vytras, K. and Walcarius, A. (2009) Electrochemical Sensors and Biosensors Based on Heterogeneous Carbon Materials. Monatshefte für Chemie-Chemical Monthly, 140, 861-889.

https://doi.org/10.1007/s00706-009-0131-9

[3] Raab, L.S., Decker, G.L., Jonas, A.J., Kaetzel, M.A. and Dedman, J.R. (1991) Glucocoticoid Regulation of Rat Liver Urate Oxidase. Journal of Cellular Biochemistry, 47, 18-30. https://doi.org/10.1002/jcb.240470104

[4] Martinez-Pérez, D., Ferrer, M.L. and Mateo, C.R. (2003) A Reagent Less Fluorescent Sol-Gel Biosensor for Uric Acid Detection in Biological Fluids. Analytical Biochemistry, 322, 238-242. https://doi.org/10.1016/j.ab.2003.08.018

[5] Gülce, H., Özyörük, H., Çelebi, S.S. and Yýldýz, A. (1995) Amperometric Enzyme Electrode for Aerobic Glucose Monitoring Prepared by Glucose Oxidase Immobilized in Poly(vinylferrocenium). Journal of Electroanalytical Chemistry, 394, 63-70. https://doi.org/10.1016/0022-0728(95)04013-E

[6] Sun, L.-X., Xu, F. and Okada, T. (1998) Studies on Optimization of a Platinum Cat- 
alyst and Porphine Modified, Pyrolytic Graphite, Amperometric, Glucose Sensor by Sequential Level Elimination Experimental Design. Talanta, 47, 1165-1174. https://doi.org/10.1016/S0039-9140(98)00195-7

[7] Campanella, L. and Tomassetti, M. (1989) Sensors in Pharmaceutical Analysis. Selective Electrode Rev., 11, 69-73.

[8] Losada, J. and Pilar, M. (1997) A Glucose Amperometric Sensor Based on Covalent Immobilization of Glucose Oxidase in Poly-2-Aminoaniline Film via Chloranil on Platinized Platinum Electrode. Electroanalysis, 9, 1416-1421. https://doi.org/10.1002/elan.1140091808

[9] Nagy, G., Von Storp, L.H. and Guilbault, G.G. (1973) Enzyme Electrode for Glucose Based on an Iodide Membrane Sensor. Analytica Chimica Acta, 66, 443-445. https://doi.org/10.1016/S0003-2670(01)82564-2

[10] Hitti, I.K.A., Moody, G.J. and Thomas, J.D.R. (1984) Glucose Oxidase Membrane Systems Based on Poly(vinyl chloride) Matrices for Glucose Determination with an Iodide Ion-Selective Electrode. Analyst, 109, 1205-1208.

https://doi.org/10.1039/an9840901205

[11] Merkoçi, A., Fabregas, E. and Alegret, S. (1999) Consolidated Biocomposite Membrane Technology for Production of Potentiometric Biosensors. Sensors \& Actuators, B, 60, 97-105. https://doi.org/10.1016/S0925-4005(99)00262-2

[12] Ali, U., Alvi, N.H., Ibupoto, Z., Nur, O., Willander, M. and Danielsson, B. (2011) Selective Potentiometric Determination of Uric Acid with Uricase Immobilized on ZnO Nanowires. Sensors and Actuator B, 152, 241-247. https://doi.org/10.1016/j.snb.2010.12.015

[13] Azmi, N.E., Ramli, N.I., Abdullah, J., Hamid, M.A.A., Sidek, H., Rahman, S.A., Ariffin, N. and Yusof, N.A. (2015) A Simple and Sensitive Fluorescence Based Biosensor for the Determination of Uric Acid Using $\mathrm{H}_{2} \mathrm{O}_{2}$-Sensitive Quantum Dots/Dual Enzymes. Biosensors and Bioelectronics, 67, 129-133. https://doi.org/10.1016/j.bios.2014.07.056

[14] Rezaei, B., Shams-Ghahfarokhi, L., Havakeshian, E. and Ensafi, A.A. (2016) An Electrochemical Biosensor Based on Nanoporous Stainless Steel Modified by Gold and Palladium Nanoparticles for Simultaneous Determination of Levodopa and Uric Acid. Talanta, 158, 42-50. https://doi.org/10.1016/j.talanta.2016.04.061

[15] Somer, G., Kalayci, S. and Ekmekçi, G. (2001) Preparation and Application of Iodide-Mercury Selective Membrane Electrode Based on Ion Exchangers. Sensors \& Actuators B, 81, 122-127. https://doi.org/10.1016/S0925-4005(01)00942-X

[16] Srinivasan, K. and Rechnitz, G.A. (1969) Selectivity Studies on Liquid Membrane, Ion Selective Electrodes. Analytical Chemistry, 41, 1203-1208.

https://doi.org/10.1021/ac60279a014 